\title{
Job Satisfaction of Employees in Commercial Banks
}

\author{
Hari Prasad Pathak
}

\begin{abstract}
This paper analyzes the level of job satisfaction among employees of commercial banks along with the consideration of gender, age and experience differences. Four commercial banks were selected using purposive sampling method for the study. Further, a total of 260 respondents were selected randomly from the four banks' head offices and branch offices located in Kathmandu Metropolis. The modified Minnesota Satisfaction Questionnaire (MSQ) was used to gather data about the job satisfaction of respondents. The results indicate that almost $66 \%$ of employees are satisfied or highly satisfied with their jobs. 'Job security' is the most significant factor of job satisfaction to the employees of commercial banks in Nepal. Level of job satisfaction does not differ significantly between male and female employees. However, there are significant differences in level of job satisfaction among various age groups of employees.
\end{abstract}

Keywords: Job satisfaction, job security, motivation, commercial bank

\section{Introduction}

Job satisfaction is a multi-dimensional attitude; it is made up of attitude towards pay, promotion, relationship with co-workers, supervision, work conditions, benefits, contingent rewards, nature of work, communication, participation, performance evaluation system of the company etc. (Cascio, 2002). Employee job satisfaction is one of the significant aspects of organizational effectiveness (Chapagai, 2011). Generally, it is an employee general attitude toward the job. Moreover, a job satisfaction is the extent to which a person is gratified or fulfilled by his or her work.

Job satisfaction is related with human resource management (HRM). Research has shown time and again that HRM practices can make important and practical differences in terms of three key organizational outcomes: productivity, quality of life and profit (Cascio, 2002). The level of job satisfaction of the employees in the organization play vital role for the retention and attraction of the competent human capital in the organization. A satisfied worker tends to be less absent from his or her job, contribute for the benefit of the company and would like to stay in the organization (Adhikari, 2009). On the other hand, a dissatisfied worker has negative attitudes and prefers to remain absent too often, always remains unhappy with the supervisor, tries to leave the company once an opportunity is available, and remains in stress (Adhikari 2009). Therefore it is very essential for the organization to create a job satisfied environment within it.

Employees' overall feelings towards the job is influenced by job security, pay and benefits, training and career advancement opportunities, opportunity to use skills and knowledge, relationship with immediate co-workers, supervisors and managers, recognition of performance, job characteristics, working environment, autonomy and independency, participation in decision making, corporate culture etc. Job satisfaction can be an important 
indicator of how employees feel about their jobs and a predictor of work behaviours such as absenteeism and turnover. It is common that employees who are satisfied with their jobs are more likely to stay with their employers. Keeping a cadre of happy and motivated employees, however, is often elusive as the expectations of employees shift. As life becomes more challenging, employees may become more stressed. Therefore, the factors long thought to satisfy employees may be shifting, depending on attributes such as the gender and age of employees. In addition to demographic factors, the economic landscape in which most companies are operating is of particular interest.

One way for organizations to gauge their knowledge of employee needs is to recognize the degree to which their perceptions are accurate when matched up against employees' perceptions. So knowing employee state on job satisfaction would provide useful information for the organizations. The core focus of this paper is to assess the present status of job satisfaction level of employees in Nepalese commercial banks and to associate the relations of employees job satisfaction with age, gender and job experience of the employees.

The paper aims at assessing the job satisfaction status of employees and identifying the significant factors that influence the job satisfaction of the employees in Nepalese commercial banks. The study also examines the relationships between job satisfaction and different demographic factors.

\subsection{Literature Review}

In the organizational study, job satisfaction occupies a central role in many theories and models of individual attitudes and behaviors. The concept of job satisfaction has been defined in many ways. However, the most-used definition of job satisfaction in organizational research is that of Locke (1976), who described job satisfaction as "a pleasurable or positive emotional state resulting from the appraisal of one's job or job experiences." Job satisfaction is the amount of pleasure or contentment associated with a job (Dubrin, 1997). Syeyen and Van Wyk (1999) mentioned that job satisfaction is a feeling of pleasure as resulting from a person's perceptions of his or her work. Mwamwenda (1995) find a link between job satisfaction and productivity, commitment, fulfillment and continuance in a job situation.

Maslow's hierarchy of human needs, ranging from lower orders to higher order of needs, is an important theory that assumes the fact that individuals may belong to the same occupational group, but may differ remarkably in their need range or levels on which these needs are satisfied. In his study, Smither (1998) indicated that most people seem to have higher order needs, such as those involving self-actualization. It follows that only individuals who have high needs for fulfillment on the job are satisfied by having a job which provides the opportunities for such needs to be fulfilled (Hackman \& Lawler, 1971). Job satisfaction is a result of employees' perception of how well their job provides those things that are viewed as important (Luthans, 2002).

Herzberg, Mausner, and Synderman (1959), found hygiene factors and motivation factors that made employees satisfied and dissatisfied on job. Hygiene factors include aspects of the working environment such as pay, company policies, supervisory practices, and other working conditions where as motivating factors include achievement, autonomy, recognition, promotion opportunities. Building on this conceptualization, Hulin and Judge (2003) noted that job satisfaction includes multidimensional psychological responses to 
one's job, and that such responses have cognitive (evaluative), affective (or emotional), and behavioral components.

Maslow (1989) postulated that within every person there exists a hierarchy of five levels of needs. They are physiological need (at the lowest level), the need for security, the social need, the need for esteem, and the need for self-actualization (at the highest level). The motivation-hygiene theory (the two-factor theory of motivation) is an extrapolation which states that all variables that make people feel either good or bad about their job can be divided into two groups i.e. motivators (satisfiers) and hygiene factors (dissatisfiers) (Herzberg, Mausner, \& Snyderman, 1959).

Gender has received a great deal of attention in job satisfaction studies. Results are, however, mix or inconclusive. Studies by Clark (1997) and Sloane and Williams (2000) showed that generally women's job satisfaction is higher than men's even though women's working condition, compensation, working status, etc., are worse than men's. Although scholarly efforts have been made to interpret these puzzling findings, but fail to provide satisfactory explanations to the paradox of the contented women workers. There have been arguments suggesting that this could be well caused by systematic difference in occupations and work content experienced by women and men and, therefore, controlling for such difference would eliminates much of this gender satisfaction gap (Dex, 1988). Hakim (1991) termed the paradox 'grateful slaves' and provided a hypothetical explanation to this puzzle from the perspective of employment commitment. She argues that women's disproportionate satisfaction with their jobs can be explained by the different life goals between women and men.

The relationship between job satisfaction and demographic factors was examined by testing the following null hypotheses:

H1: Males and females do not differ significantly regarding their levels of job satisfaction.

H2: Age groups do not differ significantly regarding their levels of job satisfaction

H3: Level of job satisfaction among employees does not differ significantly with the variation in job experience.

The first hypothesis has been tested by running Mann Whitney-test. The second and the third hypotheses have been tested by using ANOVA test. The computed p-value of the test has been compared with the 5 percent level of significant.

\section{Data and Methods}

The study uses the data collected from the structured questionnaire by administering to the respondents. It was presumed that there are certain factors that influence job satisfaction of employees. The employees' satisfaction level has been examined as possible consequences of those influencing factors. Finally, relationships between job satisfaction and other variables like - gender, age and years of experience have been measured by numerical findings using appropriate parameters. Descriptive research designs have been used for the research.

A total of 260 respondents were selected randomly and proportionately from the purposively selected four banks' head offices and branch offices located in Kathmandu Metropolis 
only. The four banks had 7,560 employees working in different offices throughout the country. Following table shows the total number of employees, proportion of employees, selected sample size and actual number of respondents from the sampled banks. Though, questionnaires were administered to 260 respondents, only 210 respondents returned the usable questionnaires. Thus, the study confined to 210 employees.

\section{Table 1: Sample banks, total number of employees, sample size, and actual respondents}

\begin{tabular}{lllll}
\hline \multicolumn{1}{c}{ Bank } & \multicolumn{1}{c}{$\begin{array}{c}\text { Total } \\
\text { employees }\end{array}$} & $\begin{array}{c}\text { Proportion of } \\
\text { employees }\end{array}$ & $\begin{array}{c}\text { Sample size } \\
\text { taken from } \\
\text { each bank }\end{array}$ & $\begin{array}{c}\text { Actual } \\
\text { respodents }\end{array}$ \\
\hline Agricultural $\quad$ Development & 3,600 & .47 & 260 X .47 $=99$ \\
Bank & & & 122 & 99 \\
Rastriya Banijya Bank & 2,600 & .34 & $260 X .34=88$ & 71 \\
Prime Commercial Bank & 360 & .06 & $260 X .06=16$ & 13 \\
Nepal Investment Bank & 1,000 & .13 & $260 X .13=34$ & 27 \\
\hline Total & 7,560 & 1.00 & 260 & 210 \\
\hline
\end{tabular}

The study uses the data collected from the structured questionnaire by administering to the respondents. It was presumed that there are certain factors that influence job satisfaction of employees. The employees' satisfaction level has been examined as possible consequences of those influencing factors. Finally, relationships between job satisfaction and other variables like - gender, age and years of experience have been measured by numerical findings using appropriate parameters. Descriptive research designs have been used for the research.

A total of 260 respondents were selected randomly and proportionately from the purposively selected four banks' head offices and branch offices located in Kathmandu Metropolis only. The four banks had 7,560 employees working in different offices throughout the country. Following table shows the total number of employees, proportion of employees, selected sample size and actual number of respondents from the sampled banks. Though, questionnaires were administered to 260 respondents, only 210 respondents returned the usable questionnaires. Thus, the study confined to 210 employees.

\section{Discussion and Analysis}

\subsection{Demographic Analysis}

The study uses the data collected from the structured questionnaire by administering to the respondents. It was presumed that there are certain factors that influence job satisfaction of employees. The employees' satisfaction level has been examined as possible consequences of those influencing factors. Finally, relationships between job satisfaction and other variables like - gender, age and years of experience have been measured by numerical findings using appropriate parameters. Descriptive research designs have been used for the research.

A total of 260 respondents were selected randomly and proportionately from the purposively 66 
selected four banks' head offices and branch offices located in Kathmandu Metropolis only. The four banks had 7,560 employees working in different offices throughout the country. Following table shows the total number of employees, proportion of employees, selected sample size and actual number of respondents from the sampled banks. Though, questionnaires were administered to 260 respondents, only 210 respondents returned the usable questionnaires. Thus, the study confined to 210 employees.

.Table 2: Respondents' information ( $\mathrm{N}=210)$

\begin{tabular}{lc}
\hline & Panel A. Respondents' age group \\
\hline Age Group & Percentage \\
\hline $21-30$ years & 31.9 \\
31-40 years & 36.7 \\
41-50 years & 26.2 \\
51 and above & 5.2 \\
\hline
\end{tabular}

Panel B. Gender of respondents

\begin{tabular}{lc}
\hline & Percentage \\
\hline Male respondents & 61.43 \\
\hline Female respondents & 38.57 \\
\hline & Panel C. Highest level of education \\
\hline Degree & Percentage \\
\hline Intermediate & 1.0 \\
\hline Bachelor & 31.0 \\
\hline Master & 67.1 \\
\hline M. Phil & 1.0 \\
\hline
\end{tabular}

Panel D. Respondents' job position

\begin{tabular}{lcc}
\hline Respondents' job position & Percentage & \\
\hline Officer & 60 & \\
\hline Non-officer & Panel E. Number of years in banking career & \\
\hline \multicolumn{4}{c}{ Experience Year } & Percentage & Mean \\
\hline $1-5$ & 50.5 & \\
$6-10$ & 17.1 & \\
$11-15$ & 9.5 & \\
$16-20$ & 2.9 & \\
$21-25$ & 13.8 & \\
$26-30$ & 6.2 & \\
\hline
\end{tabular}


Panel F. Classification of banks

\begin{tabular}{lc}
\hline Classification of banks & Percentage \\
\hline Public sector commercial bank & 50 \\
Private sector commercial bank & 50 \\
\hline
\end{tabular}

Source: Questionnaire survey 2013

1 to 5 years and 5 to 10 years of experience at present job respectively. Similarly 3 percent respondents with 16 to 20 years of experience and 6.2 percent participants are from the group of 26 to 30 years of job experience. The ratio of the public sector commercial bank and private sector bank in the sample framework was 50:50.

\subsection{Significant Factors of Job Satisfaction}

Table 3 shows that job security is found to be the most preferred attribute of job satisfaction. Likewise, pay and promotion potential has been ranked as second preferred attribute of job satisfaction by the employees of commercial banks. Similarly, relationship with co-workers and supervisors, physical work condition, 'future opportunity for career development' and use of skills and abilities in current position were ranked as 3rd, 4th, 5th and 6th preferred attributes respectively.

\section{Table 3: Ranking of job satisfaction factors in order of employees preference}

The table shows the answer to the survey question: "please rank in order of your preference 'the attributes of job satisfaction' by assigning 1 to the most preferred one and 6 to the least preferred one." Composite ranking statistic for each factor is presented in the second last column which is calculated as the sum of the product of the response percentage and the preferred value across all six preferred value (i.e. 1, $2,3,4,5,6$,$) . For example, the composite ranking statistics for the first row i.e. "job$ security" is calculated as follows: . $405 * 1+.167 * 2+.152 * 3+.095 * 4+.043 * 5+.138 * 6=$ 2.62 .

\begin{tabular}{|c|c|c|c|c|c|c|c|c|}
\hline \multirow{2}{*}{$\begin{array}{l}\text { Factors that } \\
\text { influence the job } \\
\text { satisfaction }\end{array}$} & \multicolumn{6}{|c|}{$\begin{array}{c}\text { Ranking of preference ( } 1=\text { Most preferred; } 6=\text { Least } \\
\text { preferred }\end{array}$} & \multirow{2}{*}{$\begin{array}{l}\text { Composite } \\
\text { ranking } \\
\text { statistic }\end{array}$} & \multirow[t]{2}{*}{ Result } \\
\hline & 1 & 2 & 3 & 4 & 5 & 6 & & \\
\hline Job security & $40.5 \%$ & $16.7 \%$ & $15.2 \%$ & $9.5 \%$ & $4.3 \%$ & $13.8 \%$ & 2.62 & $1^{\text {st }}$ \\
\hline $\begin{array}{l}\text { Pay and promotion } \\
\text { potential } \\
\text { Relationship with }\end{array}$ & $20.0 \%$ & $25.7 \%$ & $14.8 \%$ & $5.7 \%$ & $15.7 \%$ & $18.1 \%$ & 3.26 & $2^{\text {nd }}$ \\
\hline $\begin{array}{l}\text { Co-workers and } \\
\text { supervisors }\end{array}$ & $8.6 \%$ & $12.9 \%$ & $24.3 \%$ & $23.8 \%$ & $21.9 \%$ & $8.6 \%$ & 3.63 & $3^{\text {rd }}$ \\
\hline $\begin{array}{l}\text { Physical work } \\
\text { condition } \\
\text { Future opportunity }\end{array}$ & $10.5 \%$ & $14.8 \%$ & $19.5 \%$ & $21.9 \%$ & $19.5 \%$ & $13.8 \%$ & 3.67 & $4^{\text {th }}$ \\
\hline $\begin{array}{l}\text { for career } \\
\text { development }\end{array}$ & $9.0 \%$ & $22.4 \%$ & $14.3 \%$ & $11.9 \%$ & $13.3 \%$ & $29.0 \%$ & 3.85 & $5^{\text {th }}$ \\
\hline $\begin{array}{l}\text { Use of skills and } \\
\text { abilities in current } \\
\text { position }\end{array}$ & $11.4 \%$ & $7.6 \%$ & $11.9 \%$ & $27.1 \%$ & $25.2 \%$ & $16.7 \%$ & 3.97 & $6^{\text {th }}$ \\
\hline Total & $100 \%$ & $100 \%$ & $100 \%$ & $100 \%$ & $100 \%$ & $100 \%$ & $100 \%$ & \\
\hline
\end{tabular}

Source: Questionnaire survey 2013 


\subsection{Job Satisfaction on Individual Variable}

Table 4 reveals that about sixty percent of the responding population for this study, felt satisfied or very satisfied regarding their 'job security.' However, only 46 percent stated they were satisfied or very satisfied with the "compensation and fringe/benefits provided by their employees.' Almost 49 percent stated that they had the challenging and interesting job. The highest satisfied variable is 'relation with coworker and supervisors' with 2.85 score in a four point scale. Almost 79 percent employees were satisfied or very satisfied in this matter. The lowest satisfied variable is 'career development opportunities' where only 28 percent were satisfied or very satisfied.

Table 4: Level of job satisfaction on different factors ( $\mathrm{N}=210$ )

\begin{tabular}{|c|c|c|c|c|c|c|}
\hline & & $\begin{array}{c}\text { Very } \\
\text { dissatisfied }\end{array}$ & $\begin{array}{c}\text { Dis } \\
\text { satisfied }\end{array}$ & Satisfied & $\begin{array}{l}\text { Very } \\
\text { satisfied }\end{array}$ & Mean \\
\hline \multirow{2}{*}{ Job security } & Number & 5 & 80 & 78 & 47 & \multirow{2}{*}{2.80} \\
\hline & $\%$ & 2.4 & 38.1 & 37.1 & 22.4 & \\
\hline \multirow{2}{*}{$\begin{array}{l}\text { Compensation and fringe/ } \\
\text { benefits }\end{array}$} & Number & 43 & 70 & 78 & 19 & \multirow{2}{*}{2.35} \\
\hline & $\%$ & 20.5 & 33.3 & 37.1 & 9 & \\
\hline \multirow{2}{*}{$\begin{array}{l}\text { Relationship with co-workers } \\
\text { and supervisors }\end{array}$} & Number & 11 & 34 & 140 & 25 & \multirow{2}{*}{2.85} \\
\hline & $\%$ & 5.2 & 16.2 & 66.7 & 11.9 & \\
\hline \multirow{2}{*}{$\begin{array}{l}\text { Challenging and interesting } \\
\text { job }\end{array}$} & Number & 8 & 100 & 90 & 12 & \multirow{2}{*}{2.50} \\
\hline & $\%$ & 3.8 & 47.6 & 42.9 & 5.7 & \\
\hline \multirow{2}{*}{$\begin{array}{l}\text { Career development oppor- } \\
\text { tunities }\end{array}$} & Number & 25 & 126 & 55 & 4 & \multirow{2}{*}{2.18} \\
\hline & $\%$ & 11.9 & 60 & 26.2 & 1.9 & \\
\hline \multirow{2}{*}{$\begin{array}{l}\text { Work environment/condi- } \\
\text { tion }\end{array}$} & Number & 22 & 99 & 79 & 10 & \multirow{2}{*}{2.37} \\
\hline & $\%$ & 10.5 & 47.1 & 37.6 & 4.8 & \\
\hline \multirow{2}{*}{$\begin{array}{l}\text { Opportunity to use skills and } \\
\text { abilities in the job }\end{array}$} & Number & 9 & 119 & 77 & 5 & \multirow{2}{*}{2.37} \\
\hline & $\%$ & 4.3 & 56.7 & 36.7 & 2.4 & \\
\hline \multirow{2}{*}{ Creativeness/innovativeness } & Number & 16 & 113 & 77 & 4 & \multirow{2}{*}{2.32} \\
\hline & $\%$ & 7.6 & 53.8 & 36.7 & 1.9 & \\
\hline \multirow{2}{*}{ Recognition } & Number & 22 & 97 & 80 & 11 & \multirow{2}{*}{2.51} \\
\hline & $\%$ & 10.5 & 46.2 & 38.1 & 5.2 & \\
\hline \multirow{2}{*}{ Skill variety/rotation } & Number & 19 & 113 & 66 & 12 & \multirow{2}{*}{2.38} \\
\hline & $\%$ & 9 & 53.8 & 31.4 & 5.7 & \\
\hline \multirow{2}{*}{ Achievement } & Number & 13 & 98 & 89 & 10 & \multirow{2}{*}{2.34} \\
\hline & $\%$ & 6.2 & 46.7 & 42.4 & 4.8 & \\
\hline \multirow{2}{*}{ Responsibility } & Number & 14 & 80 & 110 & 6 & \multirow{2}{*}{2.46} \\
\hline & $\%$ & 6.7 & 38.1 & 52.4 & 2.9 & \\
\hline
\end{tabular}

Source: Questionnaire survey 2013 


\subsection{Overall Job Satisfaction}

General satisfaction is an individual's general feeling about one's own job. Results of general satisfaction, as a whole were above average (Table 5). To determine the overall satisfaction, mean value of responses to questions was found out. The mean general satisfaction score on a 4 point scale, as shown in Table 5, is 2.583. It shows that the respondents were generally satisfied with their job.

Table 5: Summary item statistics

\begin{tabular}{|c|r|r|r|r|r|r|r|}
\hline & Mean & Minimum & Maximum & Range & $\begin{array}{c}\text { Maximum / } \\
\text { Minimum }\end{array}$ & Variance & \multicolumn{1}{|c|}{$\begin{array}{c}\text { No of } \\
\text { Items }\end{array}$} \\
\hline $\begin{array}{c}\text { Item } \\
\text { Means }\end{array}$ & 2.583 & 2.229 & 3.000 & .771 & 1.346 & .033 & 39 \\
\hline
\end{tabular}

Alternatively, the overall level of job satisfaction was measured by summing response rates across all 39 items of the modified MSQ. This score was then converted into categorical data by creating four satisfaction categories based on score intervals. Total sums of 3968 scores indicated that the respondent was Very Dissatisfied, 69-97 represented as Dissatisfied interval range, 98-126 indicated Satisfied results, and scores between 127 and 156 indicated that the participant was Very Satisfied.

\section{Table 6: Overall job satisfaction}

\begin{tabular}{lll}
\hline & Frequency & Percent \\
\hline Very Dissatisfied & 0 & 0.0 \\
Dissatisfied & 76 & 36.2 \\
Satisfied & 131 & 62.4 \\
Very Satisfied & 3 & 1.4 \\
Total & 210 & 100.0 \\
\hline
\end{tabular}

Table 6 reveals that out of the 210 survey participants, no one respondent $(n=0)$ fell in the Very Dissatisfied range. However, 36.2 percent of the respondents $(n=76)$ fell in the Dissatisfied range, while 62.4 percent $(n=131)$ of the scores were within the Satisfied range and only 1.4 percent $(n=3)$ of the participants' scores fell in the very satisfied range. It could be concluded that arround 64 percent of the employees are satisfied with their job.

\subsection{Job Satisfaction and Demographic Variables}

Mann-Whitney test was run by using SPSS software to test the null hypothesis that males and females do not differ significantly regarding their levels of job satisfaction. The result is presented in Table 7 The p-value of the test is too high as compared to the 5 percent level of significance $(0.918>0.05)$, therefore no sufficient evidence has been found against the null hypothesis of 'males and females do not differ significantly regarding their levels of job satisfaction.' Thus it is concluded that there is no significance differences in the levels of job satisfaction between males and females employees of commercial banks. 
Table 7: Mean job satisfaction level of employees between male and female Mann-Whitney U

\begin{tabular}{|c|c|c|}
\hline Gender & N & Mean Rank \\
\hline Male & 129 & 105.84 \\
\hline Female & 81 & 104.96 \\
\hline Total & 210 & \\
\hline Mean difference & & 0.88 \\
\hline
\end{tabular}

\subsection{Job Satisfaction and Employees Age Groups}

In order to test the research hypothesis that age groups do not differ significantly regarding their levels of job satisfaction, ANOVA test was run by using SPSS software. The results are presented in Table 8.

Table 8: Estimates of mean satisfaction with standard errors across employees age groups

\begin{tabular}{llll}
\hline \multicolumn{4}{c}{ Panel A: Mean and standard error } \\
\hline Age groups & \multicolumn{1}{c}{$\mathbf{N}$} & \multicolumn{1}{c}{ Mean } & \multicolumn{1}{c}{ Std. Error } \\
\hline $21-30$ & 67 & 97.1343 & 1.41100 \\
$31-40$ & 77 & 100.2727 & 1.29416 \\
$41-50$ & 55 & 105.9455 & 1.22280 \\
$51-60$ & 11 & 99.9091 & 4.88868 \\
Total & 210 & & \\
\hline
\end{tabular}

Panel B: Analysis of variance (ANOVA) table of the test

\begin{tabular}{lccccc}
\hline & $\begin{array}{c}\text { Sum of } \\
\text { Squares }\end{array}$ & df & $\begin{array}{c}\text { Mean } \\
\text { Square }\end{array}$ & F & Sig. \\
\hline Between groups & 2385.786 & 3 & 795.262 & 6.381 & .000 \\
Within groups & 25674.809 & 206 & 124.635 & & \\
Total & 28060.595 & 209 & & & \\
\hline
\end{tabular}

Panel C: Post Hoc Test: Multiple comparisons

\begin{tabular}{lccc}
\hline & & Std. Error & Sig. \\
\hline \multirow{2}{*}{$21-30$} & $31-40$ & 1.86517 & .094 \\
& $41-50$ & 2.03133 & .000 \\
\hline $31-40$ & $51-60$ & 3.63190 & .446 \\
\hline $41-50$ & $41-50$ & 1.97097 & .004 \\
& $51-60$ & 3.59848 & .920 \\
\hline
\end{tabular}


F-value $=6.381$ and $p$-value $=0.000$

The p-value of the F-test is too small as compared to 0.05 , therefore, there is sufficient evidence to reject the null hypothesis and thus concluded that 'age groups differ significantly regarding their levels of job satisfaction'. The post hoc tests based on least significant difference (LSD) method suggest that between two pairs (between '21-30 year' and '41-50 year'; and between '31-40 year' and '41-50 year') of employees mean of satisfaction differ significantly.

Post hoc test was run to see the level of job satisfaction between age groups. The results of which shows that there is no significant mean difference between following four pairs:

21-30 year and 31-40 year, 21-30 year and 51-60 year, 31-40 year and 51-60 year, 41-50 year and 51-60 year

\subsection{Job Satisfaction and Year of Job Experience of Employees}

ANOVA test was run to examination the null hypothesis that level of job satisfaction among employees do not differs significantly with the variation in year of experience. The finding of the results is presented in Tables 9.

The p-value of the F-test is too small as compared to 0.05 , therefore, there is sufficient evidence to reject the null hypothesis and accept the alternative hypothesis, which means job satisfaction level differs significantly between employees having different period of job experience.

Post hoc test was run in Panel $\mathrm{C}$ of Table 9 to examine the similarity and differences in level of job satisfaction between employees' groups having different year of experience. The Post- hoc test result based on least significant difference (LSD) method suggests that job satisfaction mean differ significantly between six pairs of employees having experience years of '1-5' and '11-15'; ' $1-5$ ' and '21-25'; '6-10' and '11-15'; '6-10' and '21-25'; '11-15' and '26-30'; '21-25' and '26-30'.

By considering the mean values, it is found that the employees of age groups 31-40 and $41-50$ were more satisfied than the employees of lower age group $21-30$ and higher age group $51-60$. To be specific, middle age group of employees were more satisfied than the lower and higher age group of employees.

\section{Conclusions and Rcommendations}

The study concludes that Job security is the most significant factor of job satisfaction to the employees of commercial banks in Nepal. 'Pay and promotion potential,' 'relationship with co-workers and supervisors,' 'physical work condition,' and 'future opportunity for career development' rank the second, third, fourth, and fifth important factors of job satisfaction. 
Table 9: Mean job satisfaction level of employees across year of job experience

\begin{tabular}{llll}
\hline \multicolumn{4}{c}{ Panel A: Mean value and standard error of satisfaction } \\
\hline Year of experience & \multicolumn{1}{c}{$\mathbf{N}$} & \multicolumn{1}{c}{ Mean } & \multicolumn{1}{c}{ Std. Error } \\
\hline $1-5$ & 106 & 98.7264 & 1.09729 \\
$6-10$ & 36 & 99.8056 & 1.71122 \\
$11-15$ & 20 & 106.2500 & 2.71727 \\
$16-20$ & 6 & 108.0000 & 4.96655 \\
$21-25$ & 29 & 105.5172 & 1.83535 \\
$26-30$ & 13 & 97.2308 & 3.98901 \\
\hline Total & 210 & 100.7381 & .79959 \\
\hline
\end{tabular}

Panel B: Analysis of variance (ANOVA) table of the test

\begin{tabular}{cccccc}
\hline & $\begin{array}{c}\text { Sum of } \\
\text { squares }\end{array}$ & Df & $\begin{array}{c}\text { Mean } \\
\text { square }\end{array}$ & F & Sig. \\
\hline Between groups & 2206.591 & 5 & 441.318 & 3.482 & .005 \\
Within groups & 25854.004 & 204 & 126.735 & & \\
Total & 28060.595 & 209 & & & \\
\hline
\end{tabular}

Panel C: Post Hoc Test: Multiple comparisons

\begin{tabular}{cccc}
\hline Year of experience & $\begin{array}{c}\text { Year of experi- } \\
\text { ence }\end{array}$ & $\begin{array}{c}\text { Std. } \\
\text { Error }\end{array}$ & Sig. \\
\hline $1-5$ & $6-10$ & 2.17164 & .620 \\
& $11-15$ & 2.74452 & .007 \\
$16-20$ & 4.72421 & .051 \\
& $21-25$ & 2.35919 & .004 \\
& $26-30$ & 3.30825 & .652 \\
\hline $6-10$ & $11-15$ & 3.13962 & .041 \\
& $16-20$ & 4.96417 & .100 \\
& $21-25$ & 2.80902 & .043 \\
& $26-30$ & 3.64270 & .480 \\
\hline $11-15$ & $16-20$ & 5.24016 & .739 \\
& $21-25$ & 3.27215 & .823
\end{tabular}




\begin{tabular}{cccc} 
& $26-30$ & 4.01069 & .026 \\
\hline $16-20$ & $21-25$ & 5.04903 & .623 \\
& $26-30$ & 5.55621 & .054 \\
\hline $21-25$ & $26-30$ & 3.75753 & .029 \\
\hline
\end{tabular}

F-value $=3.482$ and p-value $=0.005$

The result of the study indicates that most of employees (64.4 percent) are satisfied and very few employees (1.4 percent) are highly satisfied with their job. No one employee is in very dissatisfied condition with their job. Level of job satisfaction does not differ significantly between male and female employees of commercial banks even though both gender characteristics differs each other by nature. This result is consistent with the result found by Barbash (1976), D’Arcy, Syrotuik, and Siddique (1984), Iiacqua, Schumacher, and Li (1995), and Thompson and McNamara (1997). The study also concludes that there are significant differences in level of job satisfaction among various age groups of employees. This is consistent with the result of Hertzberg, Mausner, Peterson, and Capwell (1957) and Jewel (1990). Job satisfaction level differs significantly between employees having different period of job experience. Job satisfaction level of employees increases with the increase in year of job experience at the initial years. But, after certain years of experience, it starts decreasing with further increasing in the year of experience.

\section{BIBLOGRAPHY}

Adhikari, D. R. (2009). Organizational behaviour ( $3^{\text {rd }}$ ed.). Kathmandu: Buddha Academic.

Asadullah, M. N., \& Fernadez, R. M. (2007). Job satisfaction and gender segregation: New evidence from matched employer-employee data. Paper presented at the Royal Economic Society's 2007 Annual Conference: University of Warwick.

Barbash, J. (1976). Job satisfaction attitudes surveys. Paris: Organization for Economic Cooperation and Development.

Black, M. M., \& Holden, E. W. (1998). The impact on productivity and satisfaction among medical school psychologists. Journal of Clinical Psychology in Medical Settings, 5(1), 117-131.

Brown, R., Curran, M., \& Cousins, J. (1983). Changing attitudes to employment? Research Paper No. 40, London: Department of Employment.

Cascio, W. F. (2002). Managing human resource (6 $6^{\text {th }}$ ed.). New Delhi: Tata McGraw-Hill.

Chapagai, R. R. (2011). Impact of employee participation on job satisfaction in Nepalese commercial banks. Journal of management, 4(1), 39-51.

Chapman, D., \& Lowther, M. (1982). Teachers' satisfaction with teaching. Journal of Education Research, 75(4), 241-247.

Clark, A.E. (1997). Job satisfaction and gender : Why are women so happy at work? Labour Economics, 4(4), 341-372. 
D’Arcy, C., Syrotuik, J., \& Siddique, C. M. (1984). Perceived job attributes, job satisfaction and psychological distress: A comparison of working men and women. Human Relations, 37(8), 603-611.

Dex, S. (1998). Women's attitudes towards work. London: Macmillan.

Dubrin, A. J. (1997). Fundamentals of organisational behaviour. Ohio: ITP.

Fao, U. G. (1976). Relations of workers' expectation to satisfaction with supervisor. In M. M. Gruneberg (Ed.), Job satisfaction: A reader. London: MacMillan.

Gruneberg, M. M. (1979). Understanding job satisfaction. London: Macmillan.

Gruneberg, M. M. (Ed.). (1976). Job satisfaction: A reader. London: Macmillan.

Hackman, R. J., \& Lawler, E. E. (1971). Employee reactions to job characteristics. Journal of Applied Psychology, 55(3), 259-286.

Hakim, C. (1991). Grateful slaves and self-made women: Fact and fantasy in women's work orientations. European Sociological Review, 7, 101-21.

Herzberg, F., Mausner, B., Peterson, R., \& Capwell, D. (1957). Job attitudes: Review of research and opinion. Pittsburgh: Psychological Services of Pittsburgh.

Herzberg, H. F., Mausner, B., \& Synderman, B. (1959). The motivation to work. New York: Wiley \& Sons.

Hulin, C. L. (1968). The effects of changes in job satisfaction levels on turnover. Journal of Applied Psychology, 52, 122-126.

Hulin, C. L., \& Judge, T. A. (2003). Job attitudes. In W. C. Borman, D. R. Ilgen, \& R. J. Klimoski (Eds.), Handbook of psychology: Industrial and organizational psychology (pp. 225-276). Hoboken, NJ: Wiley.

Iiacqua, J. A., Schumacher, P., \& Li, H. C. (1995). Factors contributing to job satisfaction in higher education. Education, 116(1), 51-61.

Jewell, L. (1990). Contemporary industrial/organizational psychology. St. Paul; West.

Jewell, L. R., Bevers, K. C., Kirby, B. J., \& Flowers, J. M. (1990). Relationships between levels of job satisfaction expressed by North Carolina Vocational Agriculture and their perceptions. (n.a.).

Judge, T. A., \& Church, A. H. (2009). Job satisfaction: Research and practice. In C. L. Cooper \& E. A. Locke (Eds.), Industrial and organizational psychology: Linking theory with practice (pp. 166-198). Oxford, UK: Blackwell.

Kramen-Kahn, B., \& Hansen, N. D. (1998). Rafting the rapids: Occupational hazards, rewards, and coping strategies of psychotherapists. Professional Psychology: Research and Practice, 29(2), 130-134.

Locke, E. A. (1976). The nature and causes of job satisfaction. In M. C. Dunnette (Ed.), Handbook of industrial and organizational psychology (pp. 1279-1349). Chicago: Rand McNally.

Locke, E. A., Fitzpatrick, W., \& White, F. M. (1983). Job satisfaction and role clarity among university and college faculty. The Review of Higher Education, 6(4), 343-365. 
Luthans, F. (2002). Organizational behavior (9 $9^{\text {th }}$ ed.). New York: McGraw-Hill.

Maslow, A. H. (1989). A theory of human motivation. In M. T. Metteson (Ed.), Management and organizational behaviour classics (pp 360-396). Homewood, III.: BPI Irwin..

Miller, N. J. (1985). A description of secondary school principals in Minnesota and their job satisfaction. (Unpublished doctoral dissertation). University of North Dakota, Grand Forks.

Mwamwenda, T. S. (1995). Job satisfaction among secondary school educators in Transkei. South African journal of education, 15(2), 84-86.

Sloane , P.J., \& Williams, H. (2000). Job satisfaction, comparison earnings and gender. Labour, 14(3), 473-501.

Smith, P. C., Kendall, L. M., \& Hulin, C. L. (1969). The measurement of satisfaction in work and retirement. Chicago, IL: Rand McNally.

Smither, R. D. (1998). The psychology of work and human performance ( $3^{\text {rd }}$ ed.). New York: Longman.

Spector, P. E. (1997). Job satisfaction: Application, assessment, causes, and consequences. Thousand Oaks: Sage.

Syeyen, G. M., \& Van Wyk, J. N. (1999). Job satisfaction: perceptions of principals and educators in urban black schools in South Africa. South African Journal of Education, 19(1), 37-44.

Thompson, D., \& McNamara, J. (1997). Job satisfaction in educational organizations: A synthesis of research findings. Educational Administration Quarterly, 33(1), $1-31$.

Townsend, P. (1979). Poverty in the United Kingdom. London: Allen Lane.

Weaver, C. (1977). Relationships among pay, race, sex, and job satisfaction. Personnel Psychology, 26, 545-557.

Weiss, D. J., Dawis, R. V., England, G. W., \& Lofquist, L. H. (1967). Manual for the Minnesota Satisfaction Questionnaire. Minnesota Studies in Vocational Rehabilitation no. 22, University of Minnesota, Minneapolis. 